\title{
2014 Kamu Personeli Seçme Sınavı (KPSS) Lisans Sınavı Sonuçlarına Göre İstatistik Bölümü Öğrencilerinin Muhasebe Dersi Testlerindeki Başarılarının Karşılaştırmalı Analizi
}

\author{
Emine Yasemin YEGINBOY ${ }^{1}$ \\ Ali ÖZDEMIR ${ }^{2}$ \\ $\ddot{O} z$
}

Yüksek Öğretim Kurulu (YÖK) tarafindan 2014 yılında alınan bir kararla, iktisadi ve idari bilimler fakülteleri dışındaki fakültelerin istatistik bölümü mezunları da, aynı kamu kurum ve kuruluşlarına başvurabileceklerdir. Bu çalışmanın temel amacı; istatistik bölümü mezunu ögrencileri ile iktisadi ve idari bilimler mezunu ögrencileri 2014 KPSS Lisans alan dersi başarılarına göre karşılaştırmaktır. Bu amaç doğrultusunda, veriler SPSS 20 programında düzenlenerek istatistiki analizler yapılmıştır. Analiz sonuçlarına göre istatistik bölümü ögrencileri iktisadi ve idari bilimler programlarındaki ögrencilerinden, özellikle işletme dersi testlerini cevaplamada daha başarllıdır. Muhasebe dersi testlerinde başarılarının ise daha düşük olduğu görülmüşürr. Ulaşılan sonuçlar doğrultusunda ögrencilerin muhasebe dersi testinde başarllarının artırllması yönünde, öğretim programlarına yapılabilecek katkılar çerçevesinde önerilerde bulunulmaya çalışılmıştır.

Anahtar Kelimeler: Kamu Personeli Seçme Sınavı (KPSS), Seçimlik Ders, Zorunlu Ders

JEL Sinıflandirma Kodlart: C1, M41, A220

Comparative Analysis of Statistics Department Students' Success on Accounting Course Tests According to 2014 Public Personnel Selection Exam (PPSE) Results for Undergraduate Degree

\begin{abstract}
In 2014 a decision had been taken by the Council of Higher Education (CoHE) accepting the students of statistics department as the graduates of faculty of economics and administrative sciences when applying to public institutions and organizations. The main objective of this study is to compare the graduates of statistics department and the graduates of faculty of economics and administrative sciences according to their achievements on 2014 PPSE undergraduate field courses. For this purpose statistical analysis had been performed by organizing the data on SPSS 20 program. According to the analysis results, it has been found that students of statistics department are more successful than the students of economics and administrative sciences programs especially on business course tests, and have less success on accounting courses. By the results obtained, it have been tried to make suggestions about the contributions that can be made to higher education programs in order to increase the success of students on accounting course test.
\end{abstract}

Keywords: Public Personnel Selection Exam (PPSE), Elective Course, Obligatory Course

JEL Classification Codes: C1, M41, A220

\footnotetext{
1 Yrd. Doç. Dr. Dokuz Eylül Üniversitesi İktisadi ve İdari Bilimler Fakültesi İşletme Bölümü, yasemin.yeginboy@deu.edu.tr

${ }^{2}$ Prof. Dr. Dokuz Eylül Üniversitesi İktisadi ve İdari Bilimler Fakültesi İşletme Bölümü, ali.ozdemir@deu.edu.tr
} 


\section{E. Y. YEĞİNBOY - A. ÖZDEMIR}

\section{GİRIŞ}

İstatistik, bilgi sahibi olunmak istenen bir kitlenin verilerinin toplanması, toplanan verilerin düzenlenmesi, analiz edilmesi ve ilişkin süreçlerde analiz yöntemlerini kullanarak birey ve nesnelerin özelliklerine uygun olarak modelleme yapan, yorumlayan, açıklayan ve sunan matematiksel bir bilim dalıdır.

Geniş bir analiz yelpazesine sahip olan istatistik, fen bilimlerinden beşeri bilimlere kadar hemen hemen bütün akademik disiplinlerde uygulanmasının yanı sıra özel sektör ile kamu sektörü ve devlet yönetiminde de karar verme amaciyla kullanılır.

Muhasebe bilimi de, işletme ve çevresini bilgi sahibi yapabilmek amaciyla parasal verileri toplayan, yasal gereklilik ve izlenme kolaylığı sağlamak için kayıt eden, kayıt edilen verileri özetleyerek, belirli analiz tekniklerinden yararlanarak yorumlayıp, işletmenin dününü ve bugününü kıyaslan, açıklayan, geleceğine yönelik verileri belirlemeye olanak sağlayan bir bilim dalıdır.

İstatistik ve muhasebe bilim dallar1; verilerinin toplanmas1, toplanan verilerin işlenerek analiz edilip yorumlanarak açıklanması geleceğe yönelik alınacak olan kararlarda bir ışık tutması yönünden gerek toplum gerekse bireyler açısından belirleyici olmaktadır.

İstatistik bölümden mezun olan "istatistikçi”lerin, muhasebe öğretimi almış iktisadi ve idari bilimler fakültesi veya iktisat fakültesinden veya işletme fakültesinden mezun olan "işletmeci”, "iktisatçı", "maliyeci” vb. bölüm mezunlarıyla çalışacakları iş alanında da yolları kesişmektedir.

Öncelikle YÖK'e bağlı üniversitelerde istatistikçileri mezun eden fakültelerde iktisadi ve idari bilimler fakültesi veya iktisat fakültesi veya işletme fakültelerinin tüm bölümlerin de ortak ders niteliğindeki muhasebe dersi ve diğer temel bölüm dersleri de yer almaktadır.

Türkiye'de yirmi altı Devlet Üniversitesi'nde Fen Fakültesi veya Fen Edebiyat Fakültesi içinde İstatistik Bölümleri yer almaktadır. İstatistik Bölümü’nden mezun olan istatistikçiler Yüksek Öğretim Kurulu (YÖK) Başkanlığı 
26.08.2014 tarihinde kendisine bir dilekçeyle yapılan başvuruya "Fen Fakültesi İstatistik Bölümü mezunlarının kamu kurum kuruluşlarının açmış olduğu sınavlarda İktisadi ve İdari Bilimler Fakülteleri mezunlarının başvurduğu yerlere başvurabilmelerinin uygun olduğuna karar verilmiştir" diye bir karar almıştır. Araştırmanın çıkış noktası bu karar olmuştur.

Araştırmanın ilk bölümlerinde istatistik, işletme, iktisat programlarının kontenjanları, uzmanlık alan dersleri, konu ağrılıkları, KPSS A kadroları genel olarak verilmiş, amaca uygun olarak literatür taraması ve 2014 KPSS Lisan Sınavı sonuçlarının analizleri yapılarak çalışma tamamlanmıştır.

\section{2014-2015 ÖĞRETIMM YILINDA İSTATISTİK BÖLÜMLERİ VE İKTISADİ VE İDARI BILIMLER FAKÜLTELERININ KONTENJANLARI}

İstatistik ile iktisadi ve idari bilimlere ilişkin kontenjan verileri, ÖSYM, 2014 Öğrenci Seçme ve Yerleştirme Sistemi (ÖSYS) Yükseköğretim Programları ve Kontenjanları Kılavuzundan derlenmiştir (osym.gov.tr, 2015a). 2014 Öğrenci Seçme ve Yerleştirme Sistemi (ÖSYS) Yükseköğretim Programları ve Kontenjanları Kılavuzu temel alındığında Türkiye'de 26 Devlet Üniversitesi'nde İstatistik Bölümü bulunmaktadır. 14 istatistik bölümü Fen Fakültesi bünyesinde öğretim verirken, 12 tanesi de Fen-Edebiyat Fakültesi bir bünyesinde bulunmaktadır.

Ankara Üniversitesi, Anadolu Üniversitesi, Bartın Üniversitesi, Cumhuriyet Üniversitesi, Dokuz Eylül Üniversitesi, Ege Üniversitesi, Furat Üniversitesi, Gazi Üniversitesi, Hacettepe Üniversitesi, Karadeniz Teknik Üniversitesi, Muğla Sttk1 Koçman Üniversitesi, Necmettin Erbakan Üniversitesi, Selçuk Üniversitesi ve Yüzüncü Y1l Üniversitesi’nin fen fakültelerinde istatistik bölümleri bulunurken; Afyon Kocatepe Üniversitesi, Amasya Üniversitesi, Bitlis Eren Üniversitesi, Çukurova Üniversitesi, Giresun Üniversitesi, Eskişehir Osmangazi Üniversitesi, Kırıkkale Üniversitesi, Mimar Sinan Güzel Sanatlar Üniversitesi, Ondokuz Mayıs 


\section{E. Y. YEĞİNBOY - A. ÖZDEMIR}

Üniversitesi, Orta Doğu Teknik Üniversitesi, Sinop Üniversitesi ve Yıldız Teknik Üniversitesi'nde ise istatistik bölümleri Fen - Edebiyat Fakültelerinde yer almaktadır

2014 KPSS Lisans sınavına giren adaylar arasında vakıf üniversitelerinden Ufuk Üniversitesi, Yaşar Üniversitesi ve İstanbul Ticaret Üniversitesi istatistik bölümlerine kayıt yaptıran öğrenciler olurken, yeterli başvuruların olmaması nedeniyle birçok vakıf üniversitesinde istatistik bölümleri kapatılmıştır. $\mathrm{Bu}$ nedenle; bazı üniversitelerde "istatistik ve bilgisayar bilimleri bölümü" adı altında ağırlıklı olarak bilgisayar öğretimi verilen bölümler açılmıştır.

2014-2015 Öğretim Yılında istatistik bölümlerinin kontenjanları (KKTC vatandaşları da dahil) 959 öğrenci sayısına ulaşabilmiştir. İstatistik bölümlerine kayıt yaptıran öğrenci sayısı en az 11 öğrenci, en fazla 82 öğrenci sayısı sınırları arasında kalmıştır. Bazı üniversitelerde ikinci öğretim programları bu öğretim yılında sonlandırılarak, yalnızca örgün öğretim programları açılmıştır.

İstatistik bölümlerinin bulunduğu üniversitelerde iktisadi ve idari bilimler fakültelerinin bulunup bulunmadığı incelendiğinde; Mimar Sinan Güzel Sanatlar Üniversitesi ve Amasya Üniversitesi dışındaki yirmi dört üniversitede İktisadi ve İdari Bilimler Fakültesi (İ̈BF), İktisat Fakültesi(İKF), İşletme Fakültesi (İF), Siyasal Bilgiler Fakültesi (SBF) ve Necmettin Erbakan Üniversitesi'nde Sosyal ve Beşeri Bilimler Fakültesi (SBBF) bulunmaktadır.

$\mathrm{Bu}$ yirmi dört üniversitedeki İ̈BF, İKF, İF, SBF veya SBBF fakültelerin kontenjanları incelendiğinde; en az 40 en fazla 15.750 öğrenci kontenjanları bulunmaktadır. En fazla kontenjan Anadolu Üniversitesi Açık Öğretim Fakültesi'ne aittir. Anadolu Üniversitesi’nde Açı Öğretim Fakültesi bulunmaktadır. Bu nedenle; Anadolu Üniversitesi Açık Öğretim Fakültesi en fazla kontenjana sahip fakültedir. Anadolu Üniversitesi Açık Öğretim Fakültesi’nde bulunan İktisat Fakültesi ve İşletme Fakültesi içerisinde yer alan yedi bölüme 24.858 öğrenci kontenjanıyla en fazla öğrenci alan üniversite olmaktadır. 2008 yılında kurulan Bitlis Eren Üniversitesi İktisadi ve İdari Bilimler Fakültesi 40 öğrenci kontenjanıyla yirmi dört üniversite arasında en az öğrenci alan fakülte 
olmaktadır. 2014-2015 öğretim yılında yirmi dört üniversitenin İ̈BF, İKF, İF, SBF veya SBBF 'ne toplam 42.917 öğrenci kontenjanı açıklanmıştır.

Yükseköğretime Giriş Sınavında (YGS) seçilen bölümlere göre puan türleri; istatistik bölümleri için MF- 1 (Matematik-Fen), işletme ve iktisat bölümleri için TM-1 (Türkçe Matematik), küresel siyaset ve uluslararası ilişkiler bölümleri ile siyaset bilimi ve uluslararası ilişkiler bölümleri için TM-2, sosyal hizmet bölümleri için TM -3 ve halkla ilişkiler ve reklamcılık bölümleri için TS-1 (Türkçe Sosyal) gerekmektedir. TM-1 ve MF-1 Matematik, TM-2 Matematik - Türkçe, TM-3 Türkçe-Edebiyat ağırlıklı ve TS-1 Sosyal Programlar puan türleri olmaktadır.

İstatistik bölümlerinde okutulan ders katalogları incelenmiştir. $\mathrm{Bu}$ kataloglardaki; iktisadi ve idari bilimler, iktisat, işletme, siyasal bilgiler ile sosyal ve beşeri bilimler fakültelerinin tüm bölümlerine ait ders kataloglarında temel alan (uzmanlık) derslerinin durumu ele alınarak aşağıdaki şekilde değerlendirilmiştir.

\section{2014-2015 ÖĞRETIM YILINDA İSTATİSTIK BÖLÜMLERININ PROGRAMLARINDA YER ALAN İKTISADİ VE İDARİ BILIMLER FAKÜLTELERİ TEMEL ALAN (UZMANLIK) DERSLERİ}

İstatistik bölümlerindeki iktisadi ve idari bilimler ilgili temel alan derslerine ilişkin veriler üniversitelerin ve bölümlerin web sayfalarındaki ders kataloglarından derlenmiştir. İstatistik bölümü öğrencilerinin KPSS Lisans sınavında cevapladıkları Hukuk, İktisat, İşletme, Maliye, Muhasebe, Çalışma Ekonomisi ve Endüstriyel İlişkiler, Kamu Yönetimi, Uluslararası İlişkiler derslerini lisans öğretimi sırasında alıp almadığı incelenmiştir. İstatistik dersi iktisadi ve idari bilimler fakültesi, iktisat fakültesi, işletme fakültesi, siyasal bilgiler fakültesi, sosyal ve beşeri bilimler fakültelerinde zorunlu derstir.

2014-2015 öğretim yılın için, istatistik bölümü bulunan fakültelerin Bolonya Süreci’ne göre düzenlenen ders katalogları incelenmiştir. İktisat, Ekonomi, İktisada Giriş, Ekonomiye Giriş dersi adı altında on üç üniversitede 1. ya da 3. yarıyılda zorunlu ders olarak okutulmaktadır. İktisat 1 ve İktisat 2 dersi olarak bir birini izleyen 2 yarıyılda programlanmıştır. 


\section{E. Y. YEĞİNBOY - A. ÖZDEMIR}

Mimar Sinan Güzel Sanatlar Üniversitesi Fen Edebiyat Fakültesi İstatistik Bölümü'nde İktisat 1, İktisat 2, İktisat 3, İktisat 4 dersleri olarak dört yarıyılda verilirken, Muhasebe 1, Muhasebe 2 dersi de 3. ve 4. Yarıyılda, Finansman dersi 5. ve 6. yarıyılda ve Yatırım Teknikleri 1 ve Yatırım Teknikleri 2 dersi de iki yarıyılda zorunlu olarak verilmektedir. Mimar Sinan Güzel Sanatlar Üniversitesi Fen Edebiyat Fakültesi İstatistik Bölümü muhasebe ve finansman derslerinin zorunlu olarak verildiği tek istatistik bölümüdür. İstatistik bölümlerinin ders kataloglarında İİBF temel (alan) dersleri EK-1'de verilmektedir.

Yirmi altı üniversitede öğretim veren istatistik bölümlerinin tümünün ders katalogları incelendiğinde, 71 adet temel alan (uzmanlık) dersi olduğu belirlenmiştir. $\mathrm{Bu}$ dersler, muhasebe, finansman, iktisat, işletme, hukuk, pazarlama, yönetim, sigorta, psikoloji, maliye ve sosyoloji alanları olmak üzere 11 alan başlığı altında Ek-1' de derlenmiştir.

Ankara Üniversitesi Fen Fakültesi İstatistik Bölümü’nde Risk Yönetimi ve Finansal Risk Analizi dersleri 7. ve 8. yarıylda zorunlu olan temel alan dersi olarak okutulmaktadır. Bu alanda başka ders yer almamaktadır. Dokuz Eylül Üniversitesi Fen Fakültesi İstatistik Bölümü’nde ise, tek zorunlu temel alan dersi olarak Finans Matematiği dersi, 6. yarıyılda verilmektedir.

İşletme konuları, İşletmeye Giriş, Genel İşletme, İşletmeye Giriş, İşletme Bilimine Giriş adı altındaki derslerle, altı üniversitenin istatistik bölümlerinde 1., 3. veya 4. yarı y1llarında zorunlu ders olarak verilmektedir.

Karadeniz Teknik Üniversitesinin İstatistik ve Bilgisayar Bilimleri İstatistik Bölümünde 3. yarı yılda "İşletme Bilimine Giriş" dersi tek temel alan dersidir.

Orta Doğu Teknik Üniversitesi İstatistik Bölümü’nde zorunlu ve/veya seçimlik hiçbir temel alan dersi verilmemektedir.

Psikoloji ve sosyoloji dersleri Çalışma Ekonomisi ve Endüstri İlişkileri Bölümlerinin temel dersleri arasında yer alır. Sosyoloji KPSS Lisans sınavlarında Kamu Yönetimi test konuları içerisinde yer alır. 
Ek-2'de temel alan derslerinin zorunlu ve seçimlik ders olarak gruplandırılması özetlenmiştir. KPSS Lisans sınavlarına girmeyi planlayan önemli oranda birçok istatistik bölümü öğrencisi muhasebe, finansman, işletme, iktisat derslerini seçmektedir.

KPSS Lisans sinavlarında özellikle bu derslerin sinav konularına ve istatistikçilerin başvurabilecekleri KPSS kadrolarına kısaca değindikten sonra karşılaştırmalı analize geçilecektir.

\section{KPSS LİSANS SINAVLARININ KONU AĞIRLIKLARI}

İstatistik bölümü bulunan tüm fakültelerin istatistik bölümü öğrencileri KPSS Lisans sınavlarında; Hukuk, İktisat, İşletme, Maliye, Muhasebe, Çalışma Ekonomisi ve Endüstriyel İlişkiler, Ekonometri, İstatistik, Kamu Yönetimi ve Uluslararası Iliş̧kiler konularındaki test sorularını cevaplandırmaktadırlar.

İktisadi ve idari bilimler fakültesi, iktisat fakültesi, işletme fakültesi, siyasal bilgiler fakültesi, sosyal ve beşeri bilimler fakültelerinin tüm bölümlerinin öğrencileri de bu alan bilgisi testlerini cevaplandırmaları gerekmektedir.

Araştırmanın amacına uygun olarak uygulanan alan testlerinden Muhasebe, İktisat, İşletme ve İstatistik ders konuları ve ağırlıkları Ek-3'te özetlenmektedir.

Her ders için 30 tane soru sorulmaktadır. Başarı notu hesaplanırken her test grubunda ham puan hesaplaması yapılmaktadır. Ham puanlar, doğru cevap sayısından yanlış cevap sayısının dörtte biri çıkarılarak hesaplanır. Her hangi bir testi yanıtlamayan adayın bu test için ham puanı hesaplanmaz. Her testin ağırlık puanı da sınav başarısında önemli olmaktadır.

\section{5. İSTATÍSTIKK BÖLÜMÜ VE İKTÍSADİ VE İDARİ BİLIMLER FAKÜLTESİ ÖĞRENĊ்/ MEZUNLARININ MÜRACAAT EDEBILLECEKLERI KPSS KADROLARI}

KPSS Lisans sınavına giren adayları alabilecekleri KPSSP 124 puan türü bulunmaktadır. KPSSP 1-8 ve KPSSP 121-124 puanları eğitim bilimleri ve din hizmetleri kadroları için belirlenen kadrolardır. 


\section{E. Y. YEĞİNBOY - A. ÖZDEMIR}

2000'li yıllara kadar KPSS-A kadrolarına ağırlıklı olarak İktisadi ve İdari Bilimler Fakültesi, Sosyal Bilimler Fakültesi ve Hukuk fakültesi mezunları başvurabilmekteyken KPSS sınavlarında başvurulan “alan (yer) yelpazesi” günden güne artış göstermektedir. Örneğin; bazı kamu kurumları mühendislik fakültesi mezunlarının (AB Genel Sekreterliği) kimileri Fen/Fen-Edebiyat Fakültesi mezunlarının (DİE) başvurularını kabul etmeye başlanmıştır. Başvuruya açık bölüm sayısı artmış olsa da uzman yardımcısı, müfettiş yardımcısı, kontrolör yardımcısı ve denetmen yardımcısı kadrolarına ağırlıkı olarak İ̈BF, SBF ve Hukuk Fakültesi mezunları arasından başvuru kabul edilmektedir. Mühendislik, mimarlık, fen/fen edebiyat, tıp gibi diğer bölümlerden başvurular alınmaya devam etse de bu durum genel yapı içinde oldukça sınırlıdır.

İktisadi ve idari bilimler, işletme/ işletmecilik programları, iktisat programları işletme-ekonomi / işletme-iktisat programları KPSS Lisans sınavında adayların müracaatlarındaki bölüm işaretlemesine bağlı olarak ayrı ayrı belirtilmektedir.

KPSSP58, KPSSP91, KPSSP105 ve KPSSP109 puan türünde muhasebe testi ağırlığ1 0,05 ağırlık puanı en düşük ağırlığa sahipken KPSSP26 ve KPSSP50 puan türünde 0,30 ağırlık payına sahiptir.

İstatistik bölümü mezunları da, iktisadi ve idari bilimler fakültesi mezunlarının başvurabilecekleri 104 KPSS puan türü kadrolarına da başvurabileceklerdir. Bu nedenle; bu KPSS A kadroları sınavlarında İstatistik bölümü mezunları yukarıda ağırlıklarını verdiğimiz temel alan derslerine ilişkin test sorularını cevaplandırmaları gerekmektedir.

\section{LITERATÜR TARAMASI}

KPSS ile ilgili olarak yapılan akademik çalışmaların büyük bir çoğunluğu öğretmenler üzerine yapılmıştır. İktisadi idari bilimler ve istatistik bölümlerine yönelik çalışma sayısı oldukça azdır. Belli başlı çalışmalar aşağıda özetlenmiştir.

- Eraslan, 2004 yılında, KPSS sınavını değerlendirmek ve öğretmen adaylarının eğitim bilimleri derslerine ilişkin düşünceleri ile bu sınav ile birlikte açılan 
KPSS hazırlık kurslarını incelemek amacıyla bir çalışma yapmıştır (Eraslan, 2004: 132-140).

- Karataş ve Güleş, 2012 yılında öğretmen adaylarının KPSS'ye ilişkin görüşlerini tespit etmek amacıyla bir makale yayınlamıştır (Karataş ve Güleş, 2012: 102-119).

- Yılmaz 2010 yılında, daha etkili bir sosyal bilgiler eğitimi için gerekli koşulların belirlenmesine yardımcı olmak amaciyla sosyal bilgiler eğitimcilerinin alanda gördükleri sorunları ve çözüm önerilerini ortaya koyan bir çalışma yapmıştır (Yılmaz, 2010: 839-867).

- Sezgin ve Duran, 2011 yılında Kamu Personeli Seçme Sınavı'nın (KPSS) Öğretmen Adaylarının Akademik ve Sosyal Yaşantılarına Yansımaları üzerine bir makale yazmıştır (Sezgin ve Duran, 2011: 1-9).

- $\mathrm{Bu}$ çalışmaya benzer biçimde alan dersleri başarı puanlarını dikkate alan çalışma 2010 yılında Kaplan tarafından yapılmıştır. Kaplan çalışmasında, öğretmen adaylarının akademik mezuniyet ortalama puanı ile KPSS puanı arasındaki ilişki derecesini araştırmıştır (Kaplan, 2010: 451-470).

KPSS sınavına yönelik tutum ve davranışları ölçen, sınavın sosyal ve psikolojik etkilerini araştıran birçok makale vardır. $\mathrm{Bu}$ makaleler arasında doğrudan bölümlerin başka bölümlerde yaptığı alan test başarısını karşılaştıran bir çalışmaya rastlanmamıştır. $\mathrm{Bu}$ yönüyle ele alınan bu çalışma, bölümler arası alan testlerini karşılaştırmaya yönelik belki de ilk çalışma olacaktır.

\section{ARAŞTIRMANIN AMACI VE ÖNEMI}

$\mathrm{Bu}$ çalışmanın temel amacı; lisans eğitimi alan istatistik bölümü öğrencilerinin öğretimleri süresince iktisadi ve idari bilimler fakültelerinde, iktisat fakültelerinde veya işletme fakültelerinin tüm bölümlerinde okutulan muhasebe, finansman, iktisat, işletme servis derslerindeki KPSS başarı durumunu değerlendirmek ve bölümler arası ders başarılarını karşılaştırmaktır. 


\section{E. Y. YEĞİNBOY - A. ÖZDEMIR}

YÖK'ün 2014 yılında almış olduğu karar çerçevesinde; istatistik bölümünden mezun olan öğrencilerin iktisadi ve idari bilimler fakültesinden mezun olan öğrencilerle aynı kamu mesleki sınavlarına ve iş alanlarına müracaatları edebileceklerdir. $\mathrm{Bu}$ nedenle; istatistik bölümlerinin ders programları içerisinde iktisadi ve idari bilimler fakültelerinde okutulan temel servis derslerinin seçimlik ve zorunlu dersler olarak yeterlilik analizi üzerinde durulmuştur.

$\mathrm{Bu}$ çalışmada; KPSS Lisans sınavında istatistik bölümü mezunu öğrencilerinin temel alan dersleri testlerindeki başarıları değerlendirilecek ve bu sinavlarda başarılarını artırmaya yönelimler ve öneriler yer alacaktır. Çalışmaya konu olan dersler bu sınavların büyük çoğunluğunda ortak olan derslerdir. KPSS Lisans sınavlarında İstatistik Bölümü mezunları ile İ̈BF (İşletme/İktisat Fakültesi) mezunlarının bu derslerle ilgili başarılarını değerlendirme çalışmaları yapılacaktır.

$\mathrm{Bu}$ çalışmanın yapılmasının amacı; KPSS ve benzeri sınavlarda fen fakültesi veya fen-edebiyat fakültesi bünyesinde yer alan istatistik bölümleri ile IIBF mezunu ögrencilerin özellikle iktisat, muhasebe, işletme ve istatistik test sinavlarının başarılarını artırmaya yönelik olarak öğretim programlarında düzenlemeler yapılması konusunda da daha yerinde kararların alınmasına olanak sağlayacak analizlerle öneriler geliştirmektir.

\section{ARAŞTIRMANIN VERİ SETI VE ANALİZ YÖNTEMİ}

Araştırmada Yükseköğretim Programlarına Göre 2014 Kamu Personel Seçme Sınavı (Lisans) Sonuçları Kitabındaki veriler kullanılmıştır. 2014-KPSS' de uygulanan testleri yanıtlayan aday sayıları, bu adayların ham puanlarından hesaplanan aritmetik ortalama ve standart sapmaları ele alınmıştır. Araştırmaya istatistik, iktisat-ekonomi ve işletme-işletmecilik programlarının öğrencileri dahil edilmiş ve bu öğrencilerin İktisat, İşletme, Muhasebe ve İstatistik testi başarıları karşılaştırmalı olarak değerlendirilmiştir.

Araştırmanın konusu; 2014 Öğrenci Seçme Ve Yerleştirme Sistemi (ÖSYS) Yükseköğretim Programları Ve Kontenjanları Kılavuzu'nda yer alan yirmi altı İstatistik Bölümü’nde 2014-2015 öğretim yılında Bolonya Süreci ders 
kataloglarında yer alan iktisadi ve idari bilimler fakültelerinde okutulan temel (alan) dersleridir.

Derslerin her birisinin ders programlarında, dersin hangi yarıyılı, zorunlu veya seçimlik olduğu, kredisi AKTS durumları dikkate alınmış ve Ek tablolarda ayrıntılı biçimde verilmiştir. 2014 KPSS Lisans sonuçlarına göre elde edilen veriler SPSS 20 programında düzenlenmiş ve tanımsal istatistik analizlerle durum değerlendirmesi yapılmıştır. Araştırma amacına uygun olarak bölümlere ve derslere göre karşılaştırma hipotezleri tek yönlü varyans analizi test edilmiştir.

\section{ARAŞTIRMANIN UYGULANMASI}

\subsection{Tanımlayıcı İstatistik Analizleri}

$\mathrm{Bu}$ araştırmada 2014 yılı KPSS Lisans sınavında yüksek öğretim programlarının içinde muhasebe derslerinin yoğun olduğu bölüm ya da programlar ile istatistik programı analize dahil edilmiştir. Muhasebe derslerinin yoğun olarak alındığ1 programlar "İktisat - Ekonomi" ve "İşletme-İşletmecilik" olarak 2 ana grup olarak ele alınmıştır. Araştırmaya alınan programların frekans dağılımı aşağıdadır.

26 istatistik bölümünden bir tanesinin ders kataloglarına ulaşılamamıştır. $\mathrm{Bu}$ programın eğitiminin 2014-2015 yılında yeni öğrenci kabulü ile sürmediği kabul edilmiştir.

Tablo 1'e göre araştırmaya dahil edilen 256 program verisinin 93 programın \%39,6's1 İktisat-Ekonomi, ve 117 programın \%49,8'i İşletme-İşletmecilik programlarıdır. Araştırmaya 25 programının \%10,6’s İstatistik Bölümü programı dahil edilmiştir.

Tablo 1. Araştırmaya Dahil Edilen Programların Frekans Dağılımı

\begin{tabular}{|l|r|r|r|}
\hline \multicolumn{2}{|l|}{ PROGRAMLAR } & \multicolumn{1}{c|}{ Frekans } & \multicolumn{1}{c|}{ Yüzde\% } \\
\hline \hline \multirow{2}{*}{ İktisadi ve İdari Bilimler } & İktisat-Ekonomi & 93 & 39,6 \\
\cline { 2 - 4 } & İşletme-İşletmecilik & 117 & 49,8 \\
\hline \hline \multirow{2}{*}{ İstatistik } & $25^{*}$ & 10,6 \\
\hline \hline Toplam & 235 & 100 \\
\hline
\end{tabular}




\section{E. Y. YEĞİNBOY - A. ÖZDEMIR}

Araştırmanın amacına uygun olarak KPSS Lisans sınavında yer alan soru grupları derslere göre Hukuk, İktisat, İşletme, Maliye, Muhasebe, Çalışma Ekonomisi ve Endüstri İlişkileri, Ekonometri, İstatistik, Kamu Yönetimi ve Uluslararası İlişkiler olarak tanımlanmıştır. Bu araştırmada; İktisat, İşletme, Muhasebe ve İstatistik derslerinin başarı durumları analiz edilmiştir. Araştırmada alınan 4 temel test grubuna yönelik programlarda katılan öğrenci sayıları aşağıdaki Tablo 2'de verilmiştir.

Tablo 2. Araştırmaya Dahil Edilen Programlarda Testlere Katılan Öğrenci Sayıları

\begin{tabular}{|l|l|l|l|}
\hline Programlar & Test Alan Dersi & Cevaplayan Program & $\begin{array}{l}\text { Cevaplayan } \\
\text { Öğrenci }\end{array}$ \\
\hline \multirow{4}{*}{ İktisat-Ekonomi } & İstatistik Dersi & 87 & 14.723 \\
\cline { 2 - 4 } & İktisat Dersi & 93 & 28.035 \\
\cline { 2 - 4 } & İşletme Dersi & 93 & 26.510 \\
\cline { 2 - 4 } & Muhasebe Dersi & 93 & 27.576 \\
\hline \multirow{4}{*}{ Isletme-Işletmecilik } & İstatistik Dersi & 108 & 19.025 \\
\cline { 2 - 4 } & İktisat Dersi & 117 & 48.752 \\
\cline { 2 - 4 } & İşletme Dersi & 117 & 49.427 \\
\cline { 2 - 4 } & Muhasebe Dersi & 116 & 49.679 \\
\hline \multirow{5}{*}{ İstatistik } & İstatistik Dersi & 25 & 3.161 \\
\cline { 2 - 4 } & İktisat Dersi & 25 & 1.460 \\
\cline { 2 - 4 } & İşletme Dersi & 25 & 1.449 \\
\cline { 2 - 4 } & Muhasebe Dersi & 24 & 1.403 \\
\hline
\end{tabular}

Kaynak: dokuman.osym.gov.tr, 2015a.

Araştırmaya dahil edilen programların öğrencileri kendi alanlarıyla ilgili dersin sorularını cevaplamıştır ancak diğer alan derslerinin sorularını cevaplamayanlar vardır. İstatistik bölümü alanında ele alınan 25 programdan sadece 1'i Muhasebe alan dersinin testini cevaplamamıştır. İktisat-Ekonomi grubunda 93 farklı programın öğrencileri analize dahil edilmiş ancak bu öğrencilerin, iktisat ders sorularını cevaplayan 28.035 iken muhasebe ders sorularını cevaplayanların sayısı 27.576'dır. Soru grubunu cevaplayan öğrenci sayılarının ayrıntısı Tablo 3'de görülmektedir. 
Tablo 3. İktisat-İşletme-Muhasebe-İstatistik Derslerinin Programlara Göre Değerlendirmesi

\begin{tabular}{|c|c|c|c|c|c|c|}
\hline 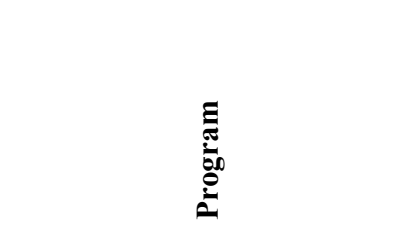 & 离 & 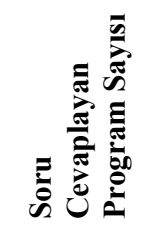 & 㤩 & 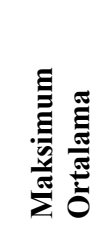 & 吾 & 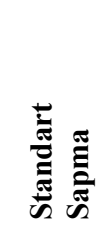 \\
\hline \multirow{4}{*}{ İktisat-Ekonomi Bölümleri } & İktisat Dersi & 93 & 1,00 & 13,95 & 4,31 & 2,17 \\
\hline & İşletme Dersi & 93 & 2,20 & 7,72 & 3,86 & 1,01 \\
\hline & Muhasebe Dersi & 93 & 0,22 & 7,05 & 2,42 & 1,32 \\
\hline & İstatistik Dersi & 87 & $-0,11$ & 4,62 & 0,98 & 0,66 \\
\hline \multirow{4}{*}{ İşletme-İşletmecilik Bölümleri } & İktisat Dersi & 117 & 0,45 & 8,06 & 2,75 & 1,25 \\
\hline & İşletme Dersi & 117 & 2,36 & 11,80 & 5,67 & 1,45 \\
\hline & Muhasebe Dersi & 116 & $-0,13$ & 7,39 & 2,87 & 1,59 \\
\hline & İstatistik Dersi & 108 & $-0,10$ & 4,33 & 1,04 & 0,69 \\
\hline \multirow{4}{*}{ İstatistik Bölümleri } & İktisat Dersi & 25 & $-0,52$ & 3,60 & 2,19 & 0,91 \\
\hline & İşletme Dersi & 25 & 2,83 & 7,35 & 4,99 & 1,07 \\
\hline & Muhasebe Dersi & 23 & $-0,08$ & 2,78 & 1,52 & 0,68 \\
\hline & İstatistik Dersi & 25 & 3,58 & 12,88 & 6,94 & 2,12 \\
\hline
\end{tabular}

Kaynak: dokuman.osym.gov.tr, 2015b; dokuman.osym.gov.tr, 2015c; dokuman.osym.gov.tr, 2015d.

Tablo 3'de programlar bazında derslerin minimum, maksimum genel ortalama ve standart sapma istatistikleri verilmektedir. Programların başarı ortalamaları aşağıda hipotezlerle karşılaştırılacağından burada sadece maksimum başarılar ayrıntılı olarak tartışılacaktır.

İktisat-Ekonomi Bölümleri öğrencileri 13,95 maksimum ortalamayla iktisat dersinde, İşletme-İşletmecilik Bölümleri öğrencileri 11,80 maksimum ortalamayla işletme dersinde ve İstatistik Bölümleri öğrencileri de 12,88 maksimum ortalamayla istatistik dersinde başarılı olmuşlardır. $\mathrm{Bu}$ maksimum ortalamalar öğrencilerin kendi alan derslerinde en yüksek başarıyı elde ettiklerini göstermektedir.

Sınava katılan öğrencilerin üniversiteleri açısından başarıları değerlendirildiğinde İktisat bölümleri arasında kendi alanlarıyla ilgili iktisat dersinde en yüksek ortalama başarı 13,95 ve muhasebe dersinde görülürken, en 


\section{E. Y. YEĞİNBOY - A. ÖZDEMIR}

yüksek başarı ise 7,05 ortalama ile Galatasaray Üniversitesi (İstanbul) İktisat Bölümü'ne aittir. İktisat bölümleri içerisinde İşletme ve İstatistik derslerinin en yüksek ortalamaları, sırasıyla 7,72 ve 4,62 puan ile Boğaziçi Üniversitesi İktisat Bölümü'ndedir. İşletme bölümlerinde muhasebe başarısı 7,39 ile Ankara Üniversitesi İşletme Bölümü’ne aittir. Boğaziçi Üniversitesi mezunları ya da öğrencileri işletme dersinde 11,80 , İktisat dersinde 8,06 ve İstatistik dersinde 4,33 ortalamaları ile en yüksek puana sahiptir.

İstatistik bölümleri arasında muhasebe dersinde en düşük ortalama puanı 2,78 ile Marmara Üniversitesi İstatistik Bölümü almıştır. İşletme dersinde 7,35 en yüksek ortalama puan ikincisi, iktisat dersinde 3,60 ile en düşük ortalama puanı ve istatistik dersinde ise 12,88 derslerinde en başarılı puanı Orta Doğu Teknik Üniversitesi İstatistik Bölümü öğrencileri almıştır.

\subsection{Programlara ve Derslere Göre Karşılaştırmalı Analizler}

Araştırmaya dahil edilen 3 program grubunun, incelenen 4 ders bazında karşılaştırması aşağıda verilen hipoteze bağlı olarak tek yönlü varyans analizi ile yapılmıştır. Araştırmada gruplar arası varyansların eşit olduğu belirlendiğinden post-hoc testlerinden Bonferroni testi ile farklılığın hangi gruplar arasında anlamlı çıktığı belirlenmiştir. Analiz sonuçları Tablo 4'dedır.

Hipotez: Derslerin başarıları programlara göre farklılık gösterir.

İktisat dersindeki başarıda, bölümlere göre anlamlı fark vardır. Bonferroni testine iktisat dersi test başarısında, iktisat bölümü öğrencileri, hem işletme hem de istatistik bölümü öğrencilerinden daha başarılıdır. Isşletme bölümü ile istatistik bölümü ögrencilerinin Ikktisat dersi testlerindeki başarıları karşılaştırıldığında ise, anlamlı bir fark olmadı̆g görülmüştür (Bonferroni testi $p=0,39>0,05$ ). 
Dokuz Eylül Üniversitesi İktisadi ve İdari Bilimler Fakültesi Dergisi Cilt:31, Sayl:1, Yll:2016, ss. 289-310

Tablo 4. Programlara Göre Alan Dersi Başarılarının Farklılık Analizi Sonuçları

\begin{tabular}{|c|c|c|c|c|c|}
\hline Dersler & Programlar & $\begin{array}{l}\text { Program } \\
\text { Sayısı }\end{array}$ & Ortalama & $\mathbf{F}$ & $\mathbf{p}$ \\
\hline \multirow{3}{*}{ İktisat Dersi } & İktisat-Ekonomi & 93 & 4,31 & \multirow{3}{*}{29,33} & \multirow{3}{*}{0,00} \\
\hline & İşletme-İşletmecilik & 117 & 2,75 & & \\
\hline & İstatistik & 25 & 2,19 & & \\
\hline \multirow{3}{*}{ İşletme Dersi } & İktisat-Ekonomi & 93 & 3,86 & \multirow{3}{*}{54,54} & \multirow{3}{*}{0,00} \\
\hline & İşletme-İşletmecilik & 117 & 5,67 & & \\
\hline & İstatistik & 25 & 4,99 & & \\
\hline \multirow{3}{*}{ Muhasebe Dersi } & İktisat-Ekonomi & 93 & 2,42 & \multirow{3}{*}{9,51} & \multirow{3}{*}{0,00} \\
\hline & İşletme-İşletmecilik & 116 & 2,87 & & \\
\hline & İstatistik & 23 & 1,52 & & \\
\hline \multirow{3}{*}{ İstatistik Dersi } & İktisat-Ekonomi & 87 & 0,98 & \multirow{3}{*}{428,90} & \multirow{3}{*}{0,00} \\
\hline & İşletme-İşletmecilik & 108 & 1,04 & & \\
\hline & İstatistik & 25 & 6,94 & & \\
\hline
\end{tabular}

İşletme dersinde 3 bölüm arasında da anlamlı fark vardır. İşletme dersinde en başarılı bölüm, kendi branş dersi olmasından dolayı, beklendiği gibi işletme bölümüdür. İşletme dersinde istatistik bölümü 4,89 ile iktisat bölümü 3,86 arasında da anlamlı fark vardır ve istatistik bölümü öğrencileri daha başarılıdır.

İstatistik dersinde istatistik bölümü hem işletme hem de iktisattan daha başarılıdır. Işsletme bölümü ile iktisat bölümü ögrrencilerinin KPSS sinavinda istatistik dersindeki başarıları aynıdır (Bonferroni testi $p=0,088>0,05$ ).

Programların derslerdeki başarıları arasındaki ilişkiye korelasyon analizi ile bakılmıştır. Anlamlı bulunan ilişkiler aşağıdaki Tablo 5'de özetlenmiştir. Korelasyonu anlamlı olmayan değerler tabloya konulmamıştır

Tablo 5. Ders Başarıları Arası Korelasyon Analizi Sonuçları

\begin{tabular}{|l|c|c|}
\hline & $\begin{array}{l}\text { Muhasebe } \\
\text { Dersi }\end{array}$ & İstatistik Dersi \\
\hline İktisat Dersi & 0,621 & - \\
\hline İşletme Dersi & 0,361 & 0,248 \\
\hline Muhasebe Dersi & - & $-0,140$ \\
\hline
\end{tabular}




\section{E. Y. YEĞİNBOY - A. ÖZDEMIR}

İktisat dersi ile muhasebe dersi başarıları arasında 0,621 düzeyinde pozitif yönlü bir ilişki vardır. İktisat dersinde yüksek başarı elde eden programların genellikle muhasebe dersindeki başarıları da diğer programlara göre yüksek olmaktadır. İşletme ile muhasebe dersi başarıları arasında ise düşük düzeyli bir ilişki vardır.

Aynı şekilde işletme dersi ile istatistik dersi başarılarında da düşük düzeyde bir ilişki vardır. Muhasebe dersi başarısı ile istatistik dersi başarısı arasında negatif çok düşük ilişki vardır. Muhasebe dersinde başarılı olan programlarda istatistik dersinde başarı azda olsa düşmektedir. İlişkinin düşük olması kesin bir değerlendirme yapmaya uygun değildir. Özellikle Boğaziçi Üniversitesi, Orta Doğu Teknik Üniversitesi gibi ele alınan alan testlerinde başarılı üniversitelerde bu geçerlilik ortadan kalmaktadır.

\section{3. Üniversitelere Göre İstatistik Bölümü Öğrencilerinin İktisadi ve İdari}

\section{Alandaki Başarılarının Değerlendirilmesi}

Araştırmanın amacına göre istatistik bölümü öğrencilerinin muhasebe dersindeki başarıları başta olmak üzere, işletme, iktisat ve istatistik başarıları karşılaştııılmış ve muhasebe dersindeki başarıya göre istatistik bölümü olan üniversitelerin, en başarılıdan en başarısıza doğru sıralaması yapılmıştır. Buna göre "muhasebe dersi"nde en başarılı üniversiteler Marmara Üniversitesi ve İstanbul Ticaret Üniversitesi olsa da, öğrenci sayılarının az olması göz önünde bulundurulmalıdır. Öğrenci sayısı fazla olan ve muhasebe alanındaki testlerde en başarılı sonuç alan adayların mezun oldukları üniversiteler sırasıyla, Ege Üniversitesi, Orta Doğu Teknik Üniversitesi ve Dokuz Eylül Üniversitesidir. Ayrıntılı değerler aşağıda Tablo 6'da gösterilmiştir. 
Dokuz Eylül Üniversitesi İktisadi ve İdari Bilimler Fakültesi Dergisi Cilt:31, Sayl:1, Yll:2016, ss. 289-310

Tablo 6. İstatistik Bölümü Olan Üniversitelerin Derslerdeki Başarı Durumları

\begin{tabular}{|c|c|c|c|c|c|c|c|c|}
\hline \multirow[b]{2}{*}{ ÜNIVERSITE } & \multicolumn{2}{|c|}{$\begin{array}{c}\text { Muhasebe } \\
\text { Dersi }\end{array}$} & \multicolumn{2}{|c|}{ İktisat Dersi } & \multicolumn{2}{|c|}{$\begin{array}{c}\text { İşletme } \\
\text { Dersi }\end{array}$} & \multicolumn{2}{|c|}{$\begin{array}{c}\text { İstatistik } \\
\text { Dersi }\end{array}$} \\
\hline & 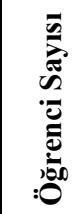 & & 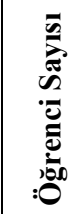 & & 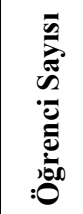 & 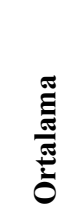 & 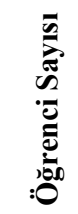 & 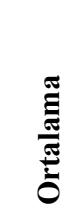 \\
\hline $\begin{array}{l}\text { MARMARA ÜNIVERSİTESİ } \\
\text { (İSTANBUL) }\end{array}$ & 8 & 2,78 & 8 & 3,34 & 8 & 3,94 & 21 & 6,95 \\
\hline İSTANBUL TİCARET ÜNIVERSITESİ & 5 & 2,45 & 5 & 1,15 & 5 & 4,70 & 7 & 6,96 \\
\hline EGE ÜNIVERSİTESİ (İZMİR) & 76 & 2,32 & 78 & 2,78 & 77 & 5,66 & 138 & 7,41 \\
\hline $\begin{array}{l}\text { ORTA DOĞU TEKNİK ÜNIVERSİTESİ } \\
\text { (ANKARA) }\end{array}$ & 50 & 2,12 & 50 & 3,60 & 48 & 7,35 & 88 & 12,88 \\
\hline $\begin{array}{l}\text { DOKUZ EYLÜL ÜNIVERSİTESI } \\
\text { (IZMIR) }\end{array}$ & 59 & 2,00 & 61 & 3,20 & 61 & 5,52 & 115 & 8,27 \\
\hline UFUK ÜNIVERSİTESİ (ANKARA) & 6 & 1,88 & 6 & 1,54 & 6 & 6,96 & 13 & 6,52 \\
\hline ANKARA ÜNIVERSİTESİ & 115 & 1,86 & 118 & 2,15 & 117 & 4,99 & 272 & 9,28 \\
\hline $\begin{array}{l}\text { ESKISSEHİR OSMANGAZİ } \\
\text { ÜNIVERSITESI }\end{array}$ & 92 & 1,86 & 100 & 2,27 & 100 & 5,46 & 197 & 6,28 \\
\hline $\begin{array}{l}\text { MİMAR SINAN GÜZEL SANATLAR } \\
\text { ÜNIVERSITESİ (İSTANBUL) }\end{array}$ & 20 & 1,75 & 19 & 2,66 & 20 & 6,45 & 33 & 6,73 \\
\hline $\begin{array}{l}\text { ONDOKUZ MAYIS ÜNIVERSİTESİ } \\
\text { (SAMSUN) }\end{array}$ & 81 & 1,64 & 82 & 2,35 & 82 & 5,13 & 266 & 5,32 \\
\hline GAZİ ÜNIVERSİTESİ (ANKARA) & 219 & 1,59 & 229 & 2,58 & 226 & 5,22 & 463 & 9,8 \\
\hline ÇUKUROVA ÜNIVERSİTESİ (ADANA) & 63 & 1,56 & 65 & 3,02 & 64 & 5,14 & 154 & 5,36 \\
\hline SELÇUK ÜNIVERSİTESİ (KONYA) & 87 & 1,51 & 89 & 2,04 & 89 & 4,84 & 205 & 5,31 \\
\hline $\begin{array}{l}\text { YILDIZ TEKNIKK ÜNIVERSİTESİ } \\
\text { (ISTANBUL) }\end{array}$ & 26 & 1,45 & 28 & 2,88 & 28 & 5,17 & 55 & 6,99 \\
\hline $\begin{array}{l}\text { ANADOLU ÜNIVERSITESİ } \\
\text { (ESKISSEHIR) }\end{array}$ & 66 & 1,42 & 67 & 2,73 & 67 & 5,20 & 116 & 6,66 \\
\hline $\begin{array}{l}\text { HACETTEPE ÜNIVERSITTESİ } \\
\text { (ANKARA) }\end{array}$ & 171 & 1,30 & 181 & 3,11 & 181 & 5,23 & 329 & 11,48 \\
\hline $\begin{array}{l}\text { MUĞLA SITKI KOÇMAN } \\
\text { ÜNIVERSITESİ }\end{array}$ & 28 & 1,29 & 29 & 2,48 & 29 & 4,59 & 76 & 5,82 \\
\hline $\begin{array}{l}\text { AFYON KOCATEPE ÜNIVERSİTESİ } \\
\text { (AFYONKARAHISAR) }\end{array}$ & 50 & 1,17 & 50 & 2,22 & 49 & 4,03 & 104 & 4,24 \\
\hline GİRESUN ÜNIVERSİTESİ & 18 & 1,06 & 18 & 1,72 & 17 & 3,66 & 40 & 4,61 \\
\hline FIRAT ÜNIVERSİTESİ (ELAZIĞ) & 49 & 1,02 & 52 & 1,48 & 51 & 4,11 & 140 & 3,58 \\
\hline KIRIKKALE ÜNIVERSITESİ & 74 & 0,97 & 75 & 1,78 & 74 & 4,59 & 156 & 5,79 \\
\hline SINOP ÜNIVERSİTESİ & 18 & $-0,03$ & 21 & 0,71 & 21 & 2,92 & 57 & 6,43 \\
\hline BAŞKENT ÜNIVERSİTESİ (ANKARA) & 13 & $-0,08$ & 13 & $-0,52$ & 13 & 2,83 & 44 & 6,48 \\
\hline
\end{tabular}

\section{SONUÇ VE ÖNERILER}

YÖK'ün 2014 yılında almış olduğu karar çerçevesinde Fen Fakülteleri'nin İstatistik Bölümü’nden mezun olan öğrencilerin İktisadi ve İdari Bilimler Fakültesi 


\section{E. Y. YEĞİNBOY - A. ÖZDEMIR}

mezunları gibi eş haklara sahip tutulmuşlardır. Bu durumda; istatistik bölümünden mezun olan öğrencilerin iktisadi ve idari bilimler fakültesinden mezun olan öğrencilerle aynı mesleki sınavlara ve iş alanlarına müracaat edebileceklerdir. İstatistik bölümü öğrencilerinin iktisadi ve idari bilimler ile ilgili test başarılarının değerlendirilmesi ve başarı durumuna göre iktisadi idari bilimler öğrencilerine göre kıyaslanması, bu kararın değerlendirilmesi ve istatistik bölümünden mezun olan öğrencilerin KPSS Lisans sınavlarındaki başarılarını görmelerini sağlayacak ve fikir verecektir.

Bu çalışmanın temel amacı; lisans eğitimi alan istatistik bölümü öğrencilerinin öğretimleri süresince iktisadi ve idari bilimler fakültelerindeki, iktisat fakülteleri veya işletme fakültelerinin tüm bölümlerinde okutulan muhasebe, iktisat, işletme ve istatistik alan dersleri ile ilgili olarak, KPSS'larındaki başarı durumunu değerlendirmek bölümler arası ders ve istatistik bölümü olan üniversitelerin başarılarını karşılaştırmak olmuştur.

2014 KPSS Lisans sınavı sonuçlarına göre, iktisat-ekonomi, işletmeişletmecilik ve istatistik bölümü öğrencilerinin muhasebe, iktisat, işletme ve istatistik alan dersleri test başarıları karşılaştırmalı olarak analiz edilmiştir.

2014 KPSS sonuçlarına göre iktisat-ekonomi alanında 93 program, işletmeişletmecilik alanında 117 program ve istatistik alanında 25 program olmak üzere 235 program analize dahil edilmiştir.

İktisat, İşletme, Muhasebe, İstatistik Derslerinin Programlara Göre başarılarına bakıldığında her programdaki öğrenciler kendi alanındaki testte daha başarılıdır. Programlara Göre Alan Dersi Başarılarının Farklılık Analizi Sonuçlarına göre iktisat dersi başarısında bölümlere göre anlamlı fark vardır. Iktisat dersi test başarısında işletme bölümü ile istatistik bölümü ögrencilerinin başarıları arasında anlamlı fark yoktur.

İşletme dersinde 3 bölüm arasında da anlamlı fark vardır. İşletme dersinde en başarılı bölüm kendi branş dersi olduğu için beklendiği gibi işletme bölümüdür. 
İşletme dersinde istatistik bölümü ile iktisat bölümü arasında da anlaml fark vardır ve istatistik bölümü ögrencileri daha başarılıdır.

İstatistik dersinde İstatistik bölümü hem işletme hem de istatistikten daha başarılıdır. İşletme bölümü ile iktisat bölümü ögrrencilerinin KPSS Lisans sinavında istatistik dersindeki başarıları aynıdır

Programların derslerdeki başarıları arasındaki ilişkiye korelasyon analizi ile bakılmıştır. İktisat dersi başarısı ile muhasebe dersi başarı arasında pozitif yönlü güçlü sayılabilecek bir ilişki bulunmuştur.

İstatistik bölümü öğrencilerinin muhasebe alanındaki başarılarına bakıldığında en yüksek ortalama 2,78 iken en düşük ortalama -0,08'dir. 2 puanın üzerine çıkan sadece 5 program varken, 3 program 1 puanın altına bunlardan ikisi de negatif değere düşmüştür. Diğer programlar 1-2 puan aralığındadır.

KPSSP puanlarına göre A grubu 121 kadrodan yaklaşı 104 kadroya iktisadi ve idari bilimlerdeki programlar da dahil olmak üzere 4 yıllık lisans eğitimi mezunları başvurabilmektedir. Bu kadrolara personel seçimi yapılırken öğrencinin aldığı puanların dağılımında muhasebe dersi testinin ağılığ $\% 5$ ile \%30 arasında değişmektedir. İktisat ve işletme derslerinin ağırlı̆̆ $\% 5$ ile $\% 60$ arasında değişirken, istatistik dersinin ağırlığı \%5 ile \%50 arasında değişmektedir.

KPSSP puanlarına göre yerleştirme yapılacağından, istatistik bölümü öğrencileri işletme dersinde gösterdiği başarıyı muhasebe dersinde de göstermelidir. İstatistik bölümlerinde sınav kapsamında konulara ağırlık veren muhasebe derslerinin zorunlu hale gelmesi kadroya başvurmada etkili olacaktır. İstatistik bölümü mezunlarının iktisadi ve idari bilimler kadrolarına başvurmaları, kontenjanı az gibi görülse de, istatistik dersinin ağırlı̆̆ının yanında diğer alan testlerinin de önemli olduğu A grubu kadrolarda muhasebe bilgisini kullanarak daha başarılı olacaktır.

Bölümler arası alan dersi başarısını karşılaştıran literatürde başka çalışma olmadığından, istatistik bölümü öğrencilerinin iktisadi idari bilimler alanındaki ders başarıları sadece KPSS verilerine göre değerlendirilmiş ve bu veri seti 


\section{E. Y. YEĞİNBOY - A. ÖZDEMIR}

kapsamında analizler yapılmıştır. KPSS sonuçlarına göre daha çok programın karşılaştırılması gerekmektedir. Böylelikle disiplinler arası eğitimin verimliliği gösterilmiş olur. Gelecek yıllarda verilerin artmasıyla birlikte zamana bağlı karşılaştırmalar yapılmalıdır.

\section{KAYNAKÇA}

ERASLAN, L. (2004), "Öğretmenlik Mesleğine Girişte Kamu Personeli Seçme Sınavı (KPSS) Yönteminin Değerlendirilmesi”, Uluslararası İnsan Bilimleri Dergisi, ISSN: 1303-5134, 132-140.

http://www.osym.gov.tr/dosya/1-69095/h/kpss-tablo-1-konularin-dagilimi.pdf, (15.02.2015).

http://dokuman.osym.gov.tr/pdfdokuman/2015/genel/Bolum1YuksekogretimProgr amlari15012015.pdf, (10.02.2015a).

http://dokuman.osym.gov.tr/pdfdokuman/2015/genel/Bolum2DHBTYuksekogreti mProgramlari15012015.pdf, (10.02.2015b).

http://dokuman.osym.gov.tr/pdfdokuman/2015/genel/Bolum3HamPuanDagilimlari 15012015.pdf, (10.02.2015c).

http://dokuman.osym.gov.tr/pdfdokuman/2015/genel/B\%C3\%B61\%C3\%BCm4Adaylarin PuanDegerAraliklarinaGoreDagilimi15012015.pdf, (10.02.2015d).

KAPLAN, Z. (2010), "Akademik Mezuniyet Ortalama Puanı ile KPSS Başarı Puanı Arasındaki İlişki”, Uludağ Üniversitesi Eğitim Fakültesi Dergisi, 23(2), 2010, 451-470.

KARATAŞ, S., GÜLEŞ, H. (2012), "Öğretmen Atamalarında Esas Alınan Merkezi Sınavın (KPSS) Öğretmen Adaylarının Görüşlerine Göre Değerlendirilmesi”, $A K U$ Kuramsal Ĕgitimbilim Dergisi - Journal of Theoretical Educational Science, 6(1), 102-119.

SEZGIN, F., DURAN E. (2011), "Kamu Personeli Seçme Sınavı'nın (KPSS) Öğretmen Adaylarının Akademik ve Sosyal Yaşantılarına Yansımaları", Türkiye Sosyal Araştırmalar Dergisi, 15(3), 1-9.

YILMAZ, K. (2010), “ Sosyal Bilimler Eğitimindeki Sorunlar ve Çözüm Önerileri, Öğretim Elemanlarının Görüşleri”, Türk Eğitim Bilimleri Dergisi, 8(4), 839-867.

ÖSYM (2014), 2014 Öğrenci Seçme ve Yerleştirme Sistemi (ÖSYS) Yükseköğretim Programları ve Kontenjanları Kılavuzu, http:// www.osym.gov.tr/ 
belge/1-20524/2014-osysogrenci-secme-yerlestirme-sistemi-kilavuzu.html, (10.02. 2015).

Ek-1. İstatistik Bölümlerinin Ders Kataloglarında İİB Temel (Alan) Dersleri

\begin{tabular}{|c|c|}
\hline MUHASEBE(12): & FİNANSMAN(10): \\
\hline $\begin{array}{l}\text { - Muhasebe } \\
\text { - Muhasebe } 1 \\
\text { - Muhasebe } 2 \\
\text { - Genel Muhasebe } \\
\text { - Finansal Muhasebe } \\
\text { - Genel Muhasebe } 1 \\
\text { - Genel Muhasebe } 2 \\
\text { - Mali Tablolar Analizi } \\
\text { - Mali Raporlar Analizi } \\
\text { - Maliyet ve Yönetim Muhasebesi } \\
\text { - Temel Muhasebe ve Finans } \\
\text { - Yönetim Muhasebesi }\end{array}$ & $\begin{array}{l}\text { - Finansal Yönetim } \\
\text { - Sermaye Piyasası ve Borsa } \\
\text { - Para Ve Sermaye Piyasaları } \\
\text { - Finans Matematiği } \\
\text { - Finansal Matematik } \\
\text { - Risk Analizi } \\
\text { - Finansal Risk Analizi } \\
\text { - Risk Yönetimi } \\
\text { - Finansman ve Yatırım Teknikleri } 1 \\
\text { - Finansman ve Yatırım Teknikleri } 2\end{array}$ \\
\hline İKTİSAT(20) & İŞLETME(11) \\
\hline \multirow{5}{*}{$\begin{array}{l}\text { - İktisat } \\
\text { - İktisada Giriş } \\
\text { - İktisada Giriş } 1 \\
\text { - İktisada Giriş } 2 \\
\text { - Genel İktisat } \\
\text { - İktisat } 1 \\
\text { - İktisat } 2 \\
\text { - İktisat } 3 \\
\text { - İktisat } 4 \\
\text { - Ekonomi } 1 \\
\text { - Ekonomi } 2 \\
\text { - Makro İktisat } 1 \\
\text { - Makro İktisat } 2 \\
\text { - Finansal İktisat } \\
\text { - Mikro İktisat } \\
\text { - Makro Ekonomi } \\
\text { - Para Banka } \\
\text { - Finansal Ekonometri } \\
\text { - Türkiye Ekonomisi } \\
\text { - Türk Ekonomi Tarihi }\end{array}$} & $\begin{array}{l}\text { - Genel İşletme } \\
\text { - Genel İşletme } 1 \\
\text { - Genel İşletme } 2 \\
\text { - İşletme Bilimine Giriş } \\
\text { - İşletmeye Giriş } \\
\text { - İşletmeye Giriş } 1 \\
\text { - İşletmeye Giriş } 2 \\
\text { - İşletme } \\
\text { - İșletme } 1 \\
\text { - İşletme } 2 \\
\text { - Genç Girişimcilik }\end{array}$ \\
\hline & PAZARLAMA (3) \\
\hline & $\begin{array}{l}\text { - Pazarlama } \\
\text { - Pazarlama İlkeleri } \\
\text { - Tüketici Hakları }\end{array}$ \\
\hline & YÖNETİM (3) \\
\hline & $\begin{array}{l}\text { - İnsan Kaynakları Yönetimi } \\
\text { - Yönetim ve Organizasyon } \\
\text { - Davranış Bilimleri }\end{array}$ \\
\hline HUKUK (5) & SİGORTA (2) \\
\hline \multirow{3}{*}{$\begin{array}{l}\text { - Hukukun Temel Kavramları } \\
\text { - Temel Hukuk } \\
\text { - Hukuk } \\
\text { - Hukuka Giriş } 1 \\
\text { - Hukuka Giriş } 2 \\
\end{array}$} & $\begin{array}{l}\text { - Sigorta İşletmeciliği } \\
\text { - Hayat Sigortası Matematiği }\end{array}$ \\
\hline & PSİKOLOJİ (3)- SOSYOLOJİ(1) \\
\hline & $\begin{array}{l}\text { - Psikoloji } \\
\text { - Psikolojiye Giriș }\end{array}$ \\
\hline MALIYE (1) & - Sosyal Psikoloji \\
\hline - Maliye & - Sosyoloji \\
\hline
\end{tabular}




\section{E. Y. YEĞİNBOY - A. ÖZDEMIR}

Ek-2. İstatistik Bölümlerinin Ders Kataloglarında İ̈BF Temel (Alan) Zorunlu ve Seçimlik Dersleri

\begin{tabular}{|c|c|}
\hline $\begin{array}{l}\text { ZORUNLU } \\
\text { DERSLER }\end{array}$ & $\begin{array}{l}\text { Muhasebe-1, Muhasebe- 2, Risk Yönetimi, Finansal Risk Analizi, Finans } \\
\text { Matematiği, Finansman ve Yatırım Teknikleri-1 ve Finansman ve Yatırım } \\
\text { Teknikleri-2, İktisada Giriş, İktisada Giriş-1, İktisada Giriş-2, İktisat -1, İktisat -2, } \\
\text { İktisat-3, İktisat-4, Ekonomi-1,Ekonomi-2, Genel İşletme, İşletmeye Giriş, } \\
\text { İşletmeye Giriş-1, İşletmeye Giriş-2, İşletme-1, İşletme-2, }\end{array}$ \\
\hline $\begin{array}{l}\text { SEÇİMLİK } \\
\text { DERSLER }\end{array}$ & $\begin{array}{l}\text { Muhasebe, Genel Muhasebe, Finansal Muhasebe, Genel Muhasebe -1, Genel } \\
\text { Muhasebe- } 2 \text {,Mali Tablolar Analizi, Mali Raporlar Analizi, Maliyet Ve Yönetim } \\
\text { Muhasebesi, Yönetim Muhasebesi, Temel Muhasebe Ve Finans, Finansal } \\
\text { Yönetim, Sermaye Piyasası ve Borsa, Para ve Sermaye Piyasaları, Finans } \\
\text { Matematiği, Finansal Matematik, Risk Analizi, Finansal Risk Analiz, } \\
\text { İktisat,İktisada Giriş, Genel İktisat, Ekonomi-1, Ekonomi -2, Makro İktisat -1, } \\
\text { Makro İktisat -2, Finansal İktisat, Mikro İktisat,Makro Ekonomi, Para Banka, } \\
\text { Finansal Ekonometri, Türkiye Ekonomisi, Türk Ekonomi Tarihi, , Genel İşletme- } \\
\text { 1, Genel İşletme -2, İşletme Bilimine Giriş, Genç Girişimcilik, Girişimcilik, } \\
\text { Hukukun Temel Kavramları, Temel Hukuk, Hukuk, Hukuka Giriş 1,Hukuka } \\
\text { Giriş 2, İşletme, İşletmeye Giriş, Pazarlama, Pazarlama İlkeleri, Tüketici Hakları } \\
\text { İnsan Kaynakları Yönetimi, Yönetim ve Organizasyon, Davranış Bilimleri, } \\
\text { Sigorta İşletmeciliği, Hayat Sigortası Matematiği, Psikoloji, Psikolojiye Giriş, } \\
\text { Sosyal Psikoloji, Maliye ve Sosyoloji }\end{array}$ \\
\hline
\end{tabular}

Ek-3. KPSS Lisans Sınavının Alan Derslerinin Kapsamları ve Ağılıkları

\begin{tabular}{|c|c|c|c|c|c|}
\hline 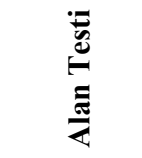 & 离 & 兰 & 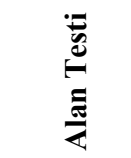 & 离 & 兰 \\
\hline \multirow{4}{*}{$\begin{array}{c}\text { Muhasebe } \\
4\end{array}$} & Genel Muhasebe & $\% 65$ & \multirow{16}{*}{$\begin{array}{c}\text { İstatistik } \\
10\end{array}$} & $\begin{array}{l}\text { Olasılık ve Stokastik } \\
\text { Süreçler }\end{array}$ & $\% 15$ \\
\hline & Mali Tablolar Analizi & $\% 15$ & & Matematiksel İstatistik & $\% 15$ \\
\hline & Ticari Aritmetik & $\% 10$ & & Yöneylem Araştırması & $\% 5$ \\
\hline & İhtisas Muhasebesi & $\% 10$ & & \multirow[b]{2}{*}{ Çok Değişkenli Analizler } & \multirow[b]{2}{*}{$\% 10$} \\
\hline \multirow{7}{*}{$\begin{array}{l}\text { İktisat } \\
7\end{array}$} & $\begin{array}{l}\text { İktisadi Doktrinler } \\
\text { Tarihi }\end{array}$ & $\% 5$ & & & \\
\hline & Mikro İktisat & $\% 30$ & & \multirow{2}{*}{$\begin{array}{l}\text { Parametrik Olmayan } \\
\text { Testler }\end{array}$} & \multirow{2}{*}{$\% 5$} \\
\hline & Makro İktisat & $\% 25$ & & & \\
\hline & Para-Banka-Kredi & $\% 10$ & & \multirow{2}{*}{ Uygulamalı İstatistik } & \multirow{2}{*}{$\% 15$} \\
\hline & Uluslararası İktisat & $\% 10$ & & & \\
\hline & Kalkınma-Büyüme & $\% 10$ & & \multirow{2}{*}{ Zaman Serileri } & \multirow{2}{*}{$\% 5$} \\
\hline & Türkiye Ekonomisi & $\% 10$ & & & \\
\hline \multirow{5}{*}{$\begin{array}{l}\text { İşletme } \\
5\end{array}$} & Temel Kavramlar & $\% 10$ & & \multirow{2}{*}{$\begin{array}{l}\text { Deney Tasarımı ve Varyans } \\
\text { Analizi }\end{array}$} & \multirow{2}{*}{$\% 10$} \\
\hline & İşletme Yönetimi & $\% 25$ & & & \\
\hline & Üretim Yönetimi & $\% 25$ & & \multirow{2}{*}{ Örnekleme } & \multirow{2}{*}{$\% 10$} \\
\hline & Pazarlama Yönetimi & $\% 20$ & & & \\
\hline & Finansal Yönetim & $\% 20$ & & Regresyon Analizi & $\% 10$ \\
\hline
\end{tabular}

Kaynak: osym.gov.tr, 2015. 